\title{
Designer's Office in Malaysia: Comparative Analysis on Space Planning and Design Issues
}

\author{
Arita Hanim Awang and Zuraini Denan
}

\begin{abstract}
A person's work environment is very important. We spend nearly as much time at work as we do at home and even for some office workers, they spend more at their office than home. Improper office environments can cause major stress for workers. Understanding office design and environment issues can help give insight on improving the atmosphere at work. Interior designer's office is the chosen typology for this research. Their offices should be the best examples in office design as they are the one who will be given a task to design their client's offices. Hence, more space requirements for their offices also gives challenge in understanding the real issues of workspace design. The objective of this research is to investigate the conditions and problems of existing designer's office in Kuala Lumpur within the scope of spatial arrangement, furniture and equipment provision. This research also attempts to get the user perception towards their existing workspace. For this purpose, a case study method is adopted. An observation of three selected designer's offices are conducted by doing a site measurement, site observation and questionnaire survey method to gather data on the user perception towards their existing workspace.
\end{abstract}

Index Terms - Office design, office layout, office setting, designer's office, office workspaces and user perception.

\section{INTRODUCTION}

Office is defined as any place where information on paper is documented, converges, preserved and used for current operations of the businesses as stated by Arora [1]. Meanwhile, Kaplan \& Aronoff [2], stated that office buildings developed from the need to plan, co-ordinate and administered activities such as filing, planning, designing, supervising, analyzing, deciding and communicating as well as processing the information and knowledge of an organization in order to be commonly accepted as a workplace.Previous research has demonstrates a significant link between the effect of office environment towards workers behaviour, perceptions and productivity [3]-[5]. Office environment features such as lighting conditions, noise and allocation of spaces per employee also contributes to employee income [6], [7], employee absenteeism[6], employee satisfaction and performance [7], [8]. Another primary aspect of the office environment that contributes to such employee behaviour is the layout of office space [9].

Manuscript received November 15, 2014; revised February 26, 2015. This work was supported in part by the Department of Architecture, Kuliyyah of Architecture and Environmental Design, International Islamic University of Malaysia. The financial support for the conference has been provided by the University and Ministry of Education Malaysia.

The authors are with Department of Architecture, Kuliyyah of Architecture and Environmental Design, International Islamic University, Malaysia (e-mail: aritahanim@gmail.com, zurainidenan@gmail.com).

\section{RESEARCH OBJECTIVE}

The paper attempt to achieve below objectives:

1) To investigate the condition and problems of existing designer's office in Kuala Lumpur.

2) To study the user perception towards their existing workspace.

3) To investigate other variables in office environment that leads towards user satisfactions and perception towards provided environment.

\section{LITERATURE REVIEW}

\section{Workplace Design}

Due to lower costs and convenience, the concept of open-plan office use continues to increase. As mentioned bySmith-Jackson \& Klein[10], open-plan designs refer to offices with individual workstations placed within an open space; sometimes divided by panels, but also include conventional shared offices with several workers in an office space.

Moreover, researchers have also reported problems with open offices from the perspective of occupants such as noise, lack of privacy and other distractions [11], [12]. According to Edward [13], individuals have their own personal space which, when violated, lead them to feel crowded and uncomfortable. It is also stated that two common factors affecting privacy are limited personal space and excessive unwanted interaction [14].

The physical arrangement of the office environment influences the level and type of social interaction between employees [15]. According toVischer [16], the good of physical office arrangement is important to helps workers perform their tasks more quickly, easily and efficiently. The layout of an office is a crucial element in overall safety. Central to layout is ease of navigation around the office and ease with which staff can complete tasks in a setting where desks, chairs, computer stations, electronic equipment and file cabinets are placed in a way that avoids overcrowding. The office layout should be efficient, yet suitably comfortable so that staff can concentrate on work and clients.

\section{Methodology ANd Procedure}

This research uses a case study method where an observation of three selected designer's offices are conducted by doing a site measurement, site observation and questionnaire survey method to gather data on the user perception towards their existing workspace. 


\section{A. Scope of Research}

In this study, the researcher only focuses on three significant variables of office interior settings, namely spatial arrangement, privacy and temperature. The questionnaire is design to get the user perception of three main areas which are: Spatial Arrangement and Furniture only. Result and Analysis

Due to the disclosure agreements with the selected offices, their company names will not be mentioned in this paper.

\section{B. General Information}

The location and detail information of the selected offices is best described in Table I below:

TABLE I: THE GENERAL INFORMATION OF SELECTED OFFICES

\begin{tabular}{|c|c|c|c|}
\hline & OFFICE A & OFFICE B & OFFICE C \\
\hline Location & $\begin{array}{c}\text { Level } 3 \text { Menara } \\
\text { Sunway, Jalan } \\
\text { Lagoon Timur, } \\
\text { Bandar } \\
\text { Sunway, } \\
\text { Petaling Jaya, } \\
\text { Selangor, 46150 }\end{array}$ & $\begin{array}{c}\text { 3rd Floor, } \\
\text { Megan Avenue } \\
\text { 1, JlnTunRazak } \\
\text { 50400 Kuala } \\
\text { Lumpur, } \\
\text { Wilayah } \\
\text { Persekutuan } \\
\text { Kuala Lumpur, } \\
\text { Malaysia. } \\
\end{array}$ & $\begin{array}{c}\text { D8, M, Blok D Kl } \\
\text { Plaza,Jln Bukit } \\
\text { Bintang,55100 } \\
\text { Kuala } \\
\text { Lumpur,Wilayah } \\
\text { Persekutuan }\end{array}$ \\
\hline $\begin{array}{l}\text { Type of } \\
\text { building: }\end{array}$ & Commercial & Commercial & Commercial \\
\hline $\begin{array}{c}\text { Sqft. of the } \\
\text { Area: }\end{array}$ & $1511 \mathrm{sqft}$ & $1600 \mathrm{sqft}$ & 1500 sqft approx. \\
\hline No. of staff & 25 & 15 & 10 \\
\hline $\begin{array}{c}\text { Space } \\
\text { provided: }\end{array}$ & $\begin{array}{c}\text { Reception / } \\
\text { lobby } \\
\text { Studio area } \\
\text { Managers room } \\
\text { Pantry } \\
\text { Filing Area }\end{array}$ & $\begin{array}{c}\text { Reception / } \\
\text { lobby } \\
\text { Studio area } \\
\text { Managers room } \\
\text { Meeting area } \\
\text { Pantry } \\
\text { Filing Area }\end{array}$ & $\begin{array}{c}\text { Reception / lobby } \\
\text { Studio area } \\
\text { Managers room } \\
\text { Pantry } \\
\text { Filing Area } \\
\text { Store Area }\end{array}$ \\
\hline $\begin{array}{l}\text { Equipment } \\
\text { provided: }\end{array}$ & $\begin{array}{l}\text { Computers } \\
\text { Printers } \\
\text { Copiers } \\
\text { Binders }\end{array}$ & $\begin{array}{l}\text { Computers } \\
\text { Printers } \\
\text { Copiers } \\
\text { Binders }\end{array}$ & $\begin{array}{l}\text { Computers } \\
\text { Printers } \\
\text { Copiers } \\
\text { Binders }\end{array}$ \\
\hline
\end{tabular}

\section{Observation Analysis}

From the observation, the researcher has divided into two sections looking on the space planning and office environment.

\section{1) Space planning}
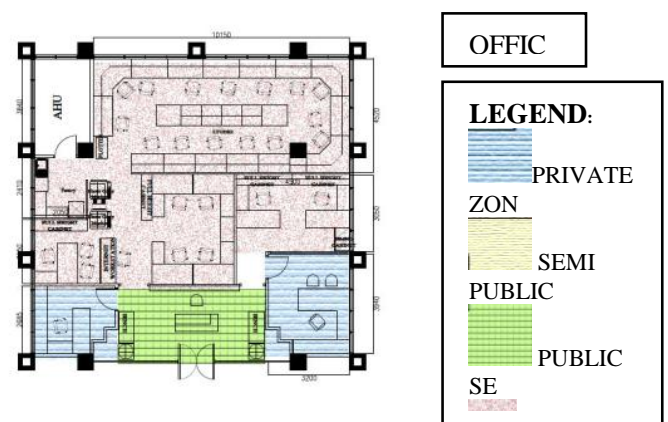

Fig. 1. The figure above shows the layout plan for office A which have been indicated with the zoning indicator.

Office $\mathrm{A}$ is adopting cluster office layouts which have segregated the zoning into a cluster. The furniture arrangement thus follows the zoning and is divided into focusing group. This type of layout gives proper indicator to visitor on where they will be allowed to enter and where they should not. However, the problems with this company is that they did not provide a semi public zone which usually comprises meeting room or discussion area to cater the visitor, clients or suppliers who wish to see their employees. This situation has leaded into misused of space where the employees have used their studio area as a meeting place.

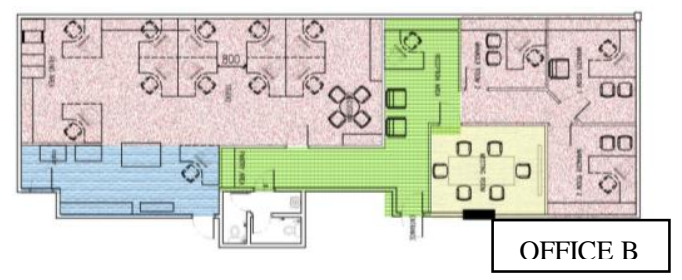

Fig. 2. The figure above shows the layout plan for office B which have been indicated with the zoning indicator.

Office B is also adopting cluster office layouts which have segregated the zoning into a cluster. There is not much interferences from the client in their working area as there is a clear indicator of space segregation and that the position of meeting area which near to the lobby add to the advantage. Same goes with Office layout $\mathrm{C}$. The space definition is clear to their client and visitor gives privacy and security towards their staff working spaces.

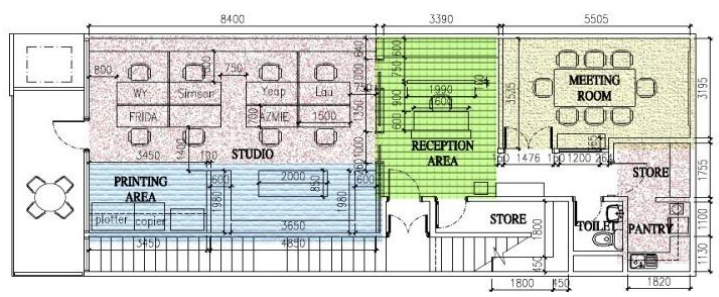

Fig. 3. The figure above shows the layout plan for office $C$ which have been indicated with the zoning indicator.

\section{2) Office environment}

Cluttered space and insufficient storage is the most common scenario observed by researcher.

a) Cluttered space / insufficient storage
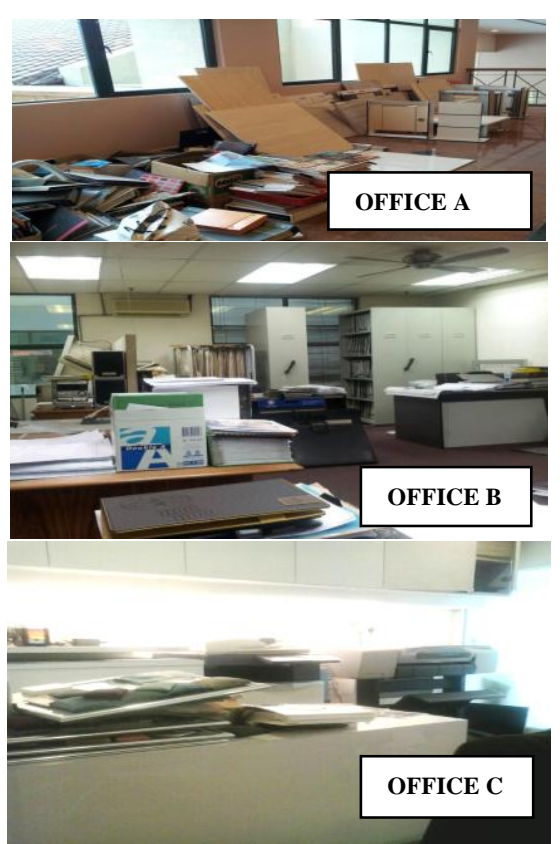

Fig. 4. The above pictures show the condition of each office. 
There is similarity between these three offices and the most problems which have been observed are the lack of storage for material and product samples and insufficient space for drawings storage. These leads to clutter spaces making the office environment look cramp and messy.

\section{3) Crowded space}

In one case of Office A, as there is no allocation of meeting area or discussion area for meeting with clients or suppliers, the meeting end up being conduct in the studio working area makes it uncomfortable for the staff. Office B, also a little bit cramp in terms of the in-proper distances between workstation.
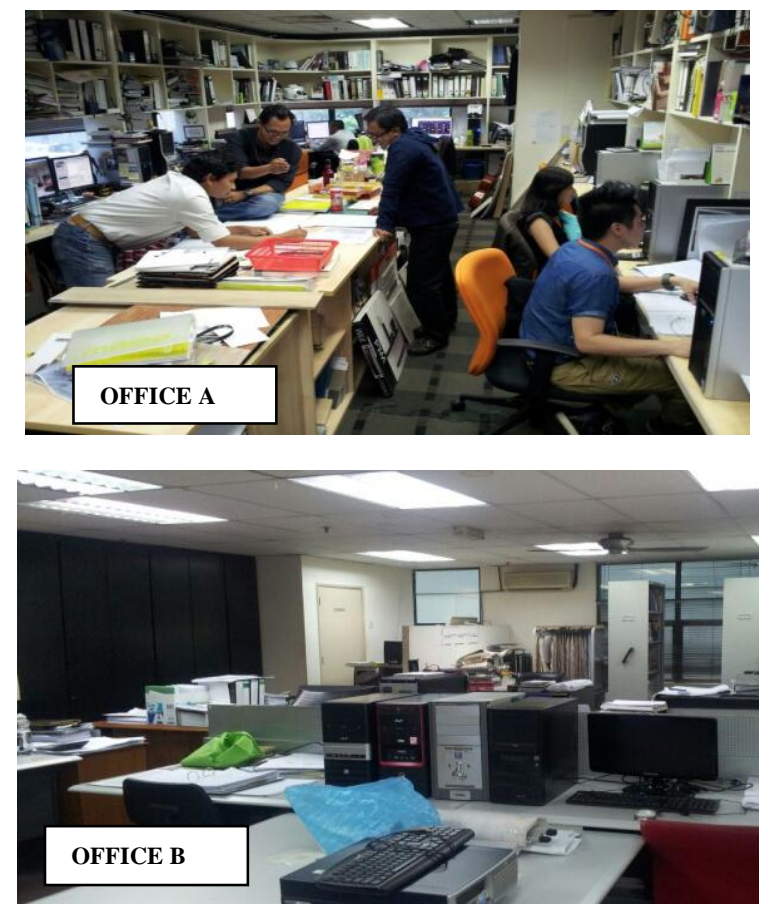

Fig. 5. The above pictures show the condition of each office.

\section{Survey Analysis}

In this survey, researcher use adopts and adapts questionnaire to the employees of each offices. The questionnaires consist of 12 questions on their perception towards variables related to the office condition.

Spatial Arrangement section will cover on whether the office layout is promoting communication between colleges as communications is an important factor in designer's nature of work. This section will also cover the perception of privacy acceptability. The second section which is the Furniture, the researcher is trying to get the user perception on the flexibility and comfort ability of the furniture for extra working hour. The last section is to get the user perception on the office temperature and whether that temperature affected their focus.

The level of disagreement between office A, B and C are high and this shows that the existing furniture provided by their companies is limited in flexibility to adjust or to re-arrange their workstation. To link this result with observation by researcher, some of their furniture can be adjusted but only in certain aspect like the backrest only but not the height, while some height can be adjusted but the backrest is not. Limited spaces in the office also make it hard to re-organize their workspace.
Question 1: Your furniture is flexible to adjust, re-arrange or re-organize?

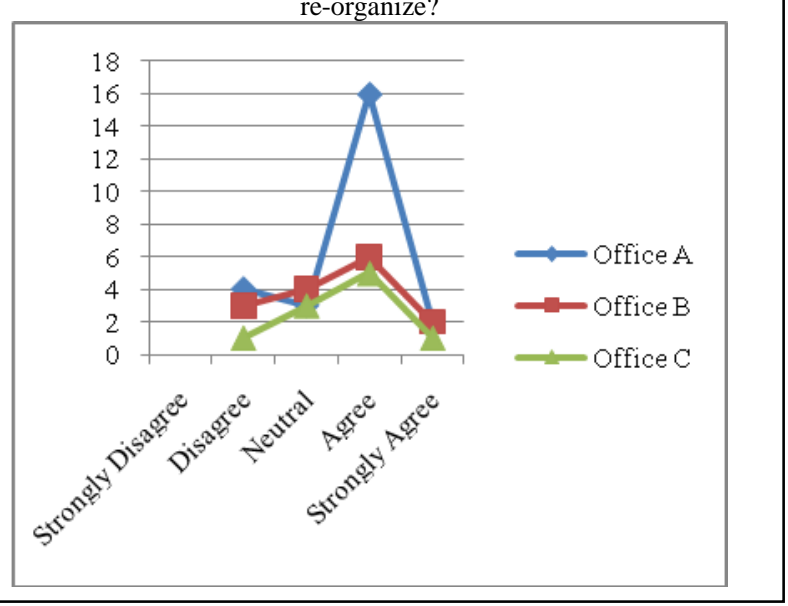

Fig. 6. The above graft shows the perception of each offices employees on their existing furniture provided by their office managements.

Question 2: Your furniture is comfortable enough so that you can work without getting tired till $5 \mathrm{pm}$ ?

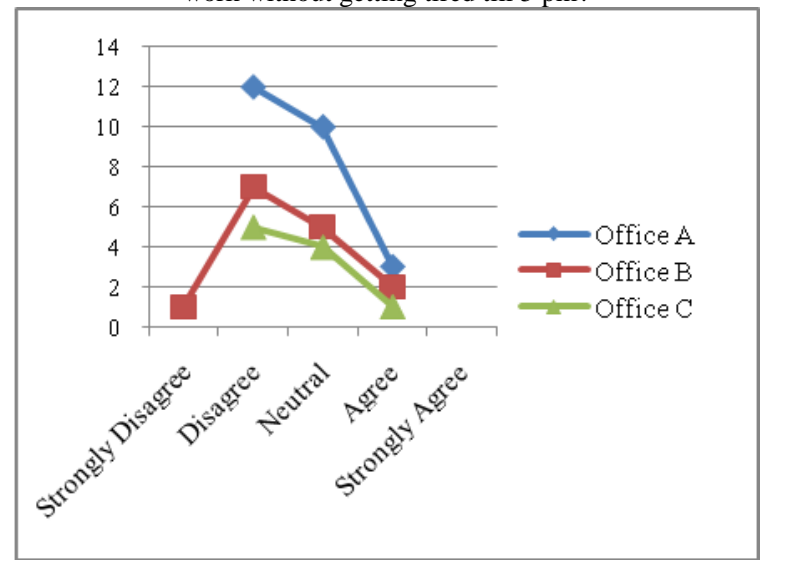

Fig. 7. The above graft shows the perception of each offices employees on their level of comfort ability in seating on their existing furniture.

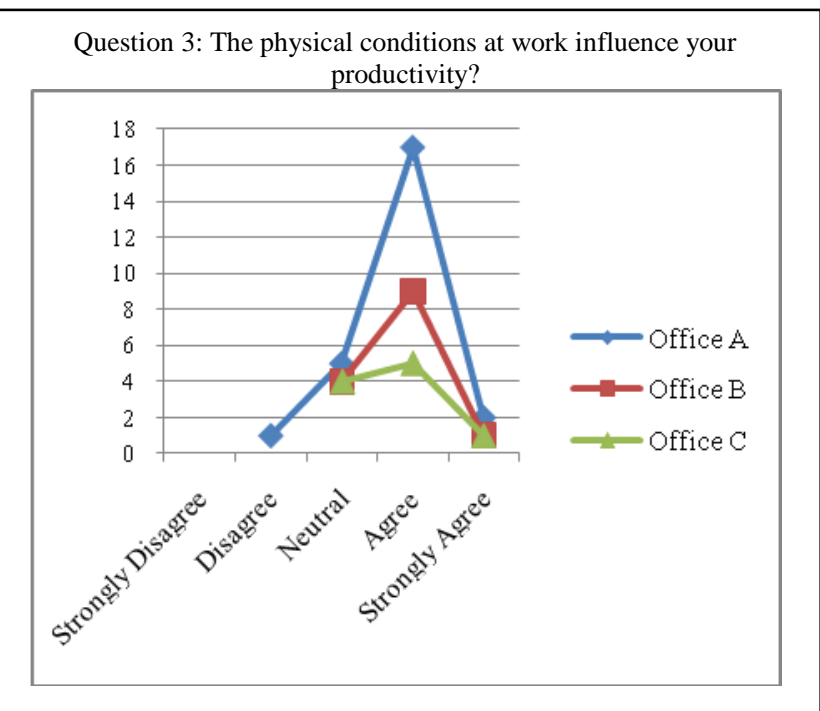

Fig. 8. The above graft shows that most of the employees in each offices agree that physical conditions at work influence their productivity.

The second questions results also reflect the first question. 
As the furniture is not flexible to adjust, most of the employees are disagree and about their comfort level to work without getting tired until $5 \mathrm{pm}$. Furniture ergonomic is really important as it will affect the employees seating posture and that will also affect their health for long term. Companies or management should give more attentions to this matter.

Through this result, it can be seen that most of the employees agree that physical conditions of their office influence their productivity. This result is parallel with findings from literature review from numerous researchers. The physical conditions consist of a few variables such as furniture, furniture layout, lighting and temperature.

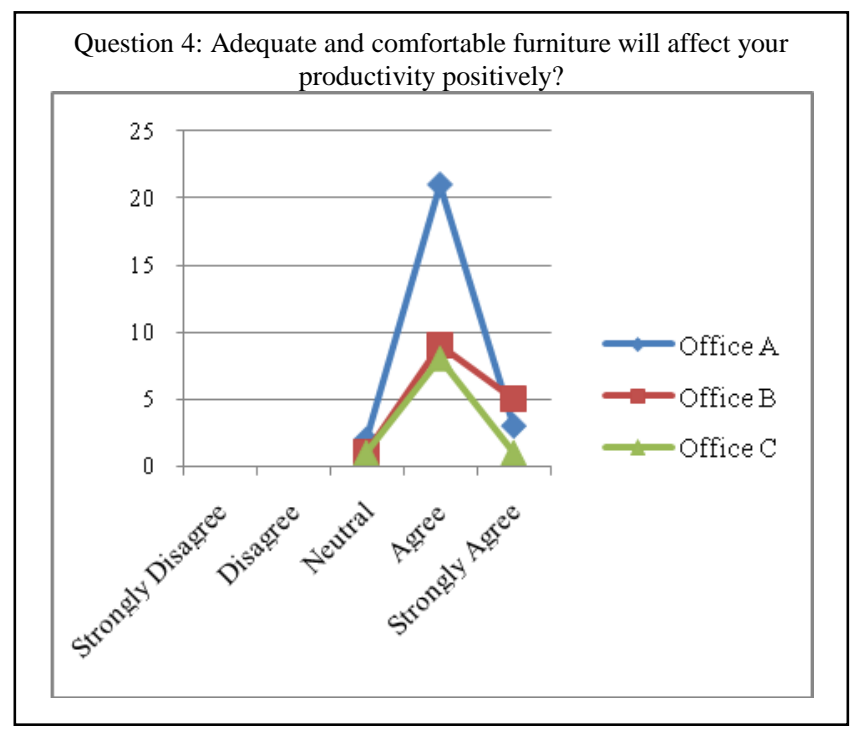

Fig. 9. The above graft shows the employees perception on the influence of adequate and comfortable furniture towards their productivity.

Most of the employees agree that adequate and comfortable furniture will give a positive affects towards their productivity This shows that the employees value furniture comfort ability as one of the influence factors.

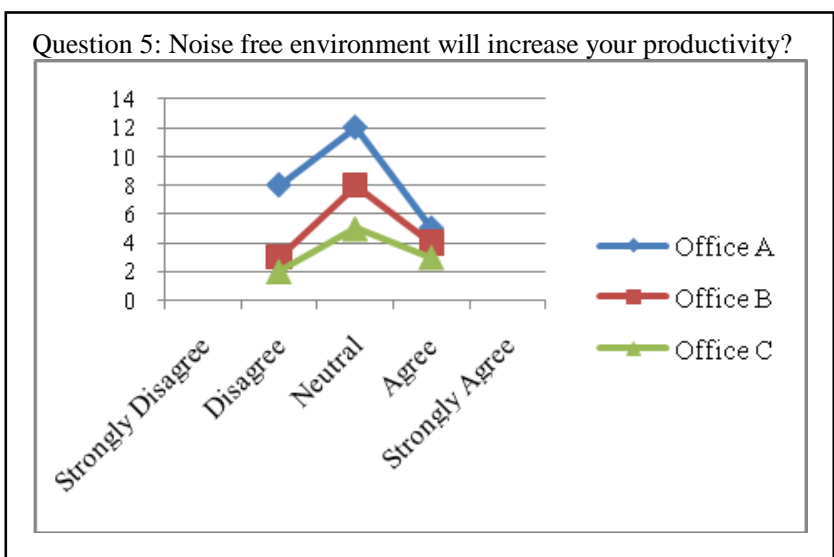

Fig. 10. The above graft shows the result of employees perception of noise free environment.

In this graft, it can be seen that most of the employees are neutral on the effects of noise free environments towards their productivity. This maybe because of personal definition of noise between employees is different. Some people prefer to work in vibrant and with background music while some may think that background music is part of the noise.
Question 6: Room temperature affects your normal level of productivity?

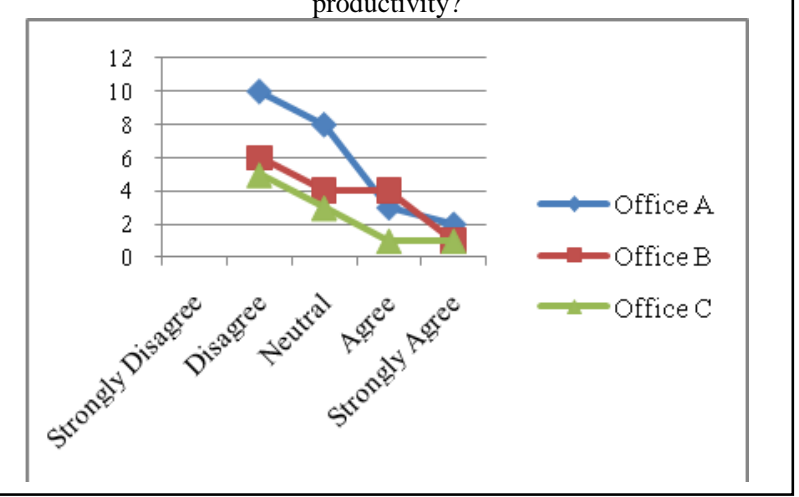

Fig. 11. The above graft shows the employees perceptions of the room temperature influence towards their productivity.

Meanwhile, this result shows that temperature in the other hand is agreeable between employees as one of the factors that will affect their level of productivity. This makes temperature as one of the prominent variables in office condition and productivity.

Question 7: Your workspace is provided with efficient lighting so that you can work easily without strain in your eyes?

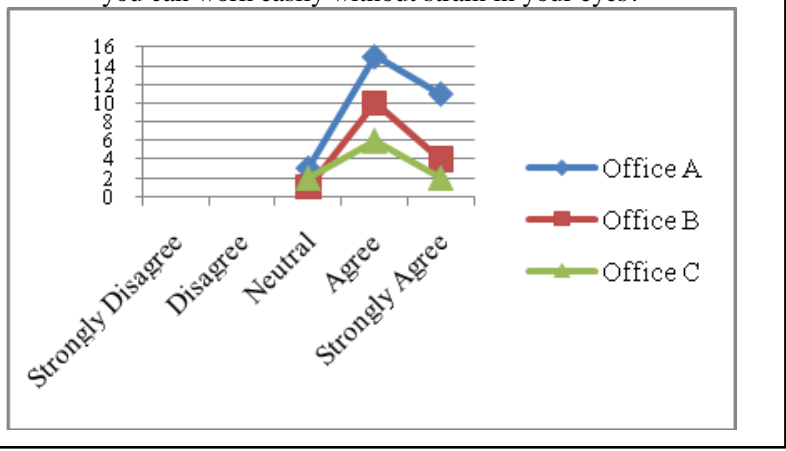

Fig. 12. The above graft shows the result of employees perceptions towards their existing lighting condition in their offices.

In Question 7graft, most of the employees agree that their existing lighting in their offices is adequate and that they can work easily without strain in their eyes.

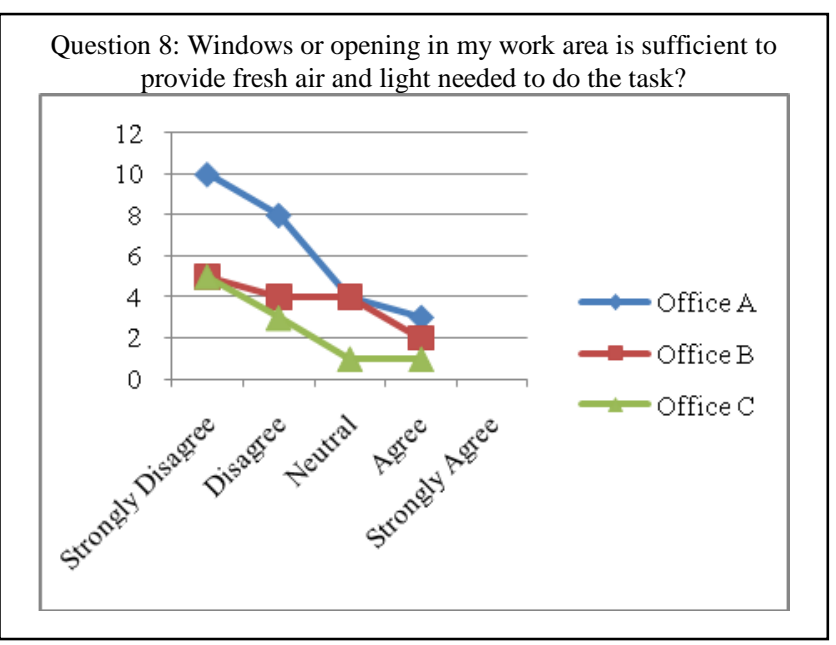

Fig. 13. The above graft shows the employees perceptions towards windows or opening provisions in their office.

In this result, it can be seen that, most of employees does 
not get enough window opening that will provide sufficient fresh air and light. The lighting in the office depended to artificial lighting most of the time. Although the employees are satisfied with the provision of light in their office, the implications is more towards the employers as the cost of energy consumption will be more. Daylight and fresh air may give different effect towards the benefit of both parties.

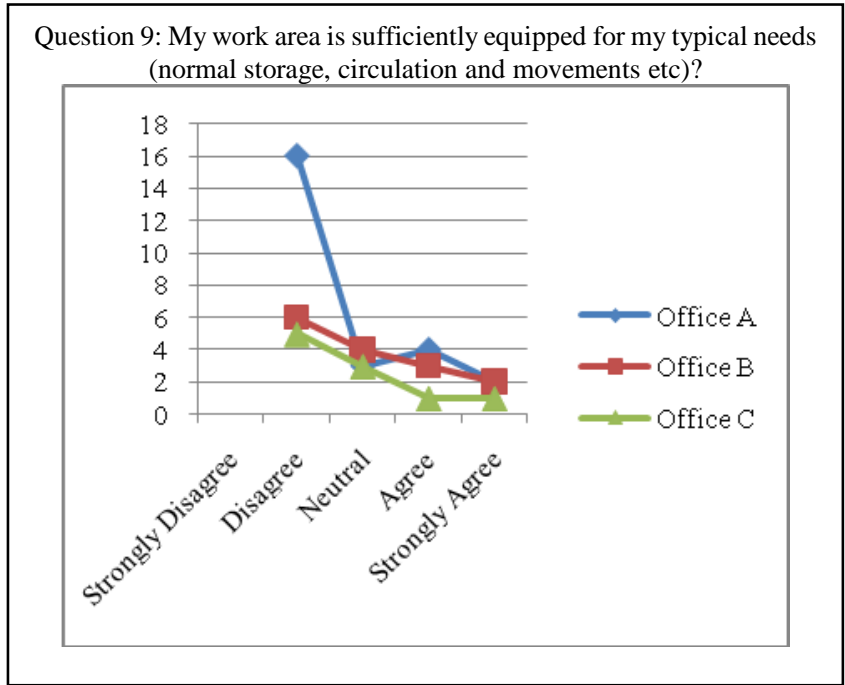

Fig. 14. The above graft shows the result of employees perceptions towards the provision of storage in their office and level of circulation.

The results from this questions shows that most of the employees disagree with the provisions of storage and movements in their area. This result supported the researcher observations on the clutter problems faced by each office. This problem usually happened because of limited office space and un-updated storage systems by the office managements. Nowadays, office Furniture Company has come out with a lot of innovative choices of office storage that can solve the cluttered problems in small office spaces. It is understandable that upgrading storage or rearranging the office layout will requires some budgets for the companies; however companies should be looking into this matter in order to create more productive environment.

Question 10: Favourable environment conditions (less noise, suitable temperature etc.) in the office building will increase your productivity at work.

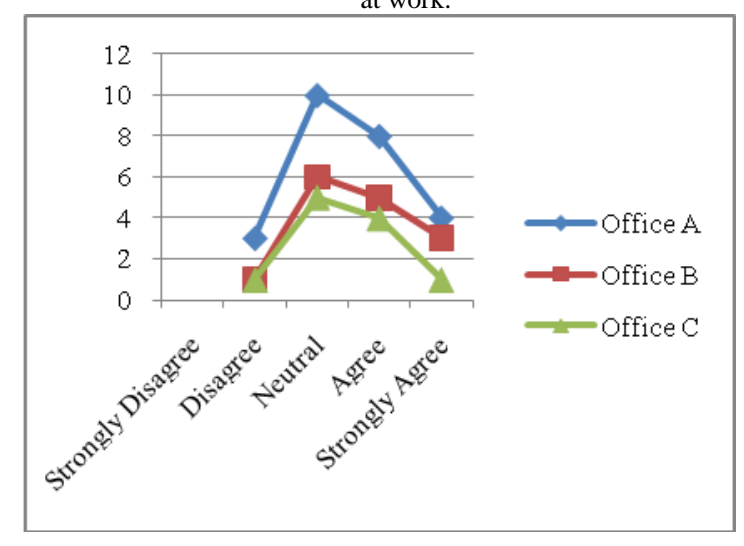

Fig. 15. The above graft shows the result of employees perceptions towards the favorable office environment.
Question 11: Unfavourable environment conditions (loud noise, un-suitable temperature etc.) in the office building will decrease your productivity at work.

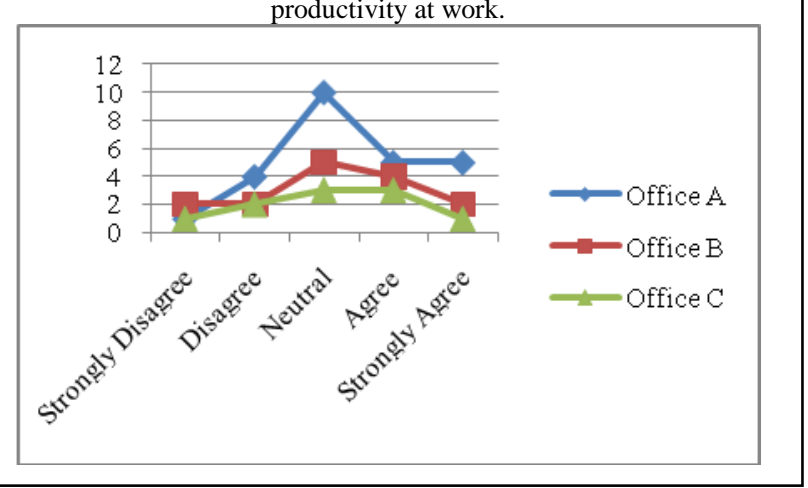

Fig. 16. The above graft shows the result of employees perceptions towards the unfavorable office environment.

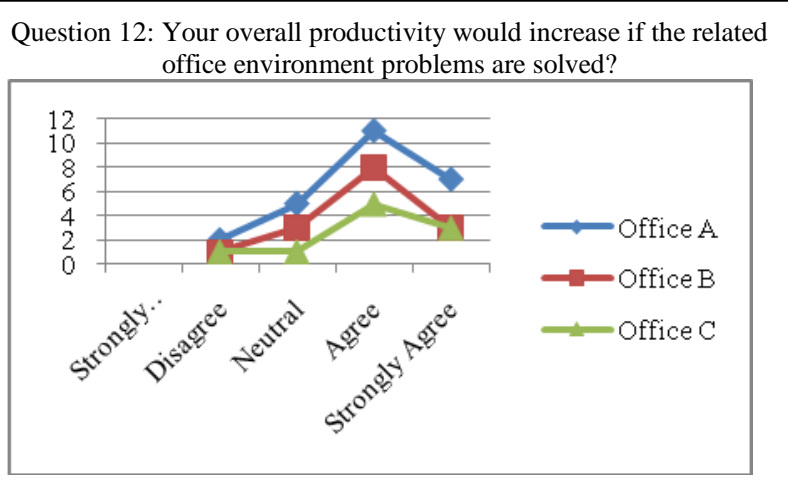

Fig. 17. The above graft shows the result of employees perceptions on their overall productivity relations with office environment.

From this survey, it can be concluded that a big percentage of staff agree that favorable working environment (less noise, suitable temperature etc) in the office building will increase their productivity at work. It is also revealed that the offices management did not provide enough flexibility in adjusting the furniture and workstation.

\section{CONCLUSION}

As for the conclusion, three key elements which are significant in office design in Malaysia have been clarified; space definition, communal area (such as meeting or discussion area) and storage provision. A clear space definition between public spaces, private or semi private is really important in order to make sure that the staff privacy is taken care of. It is also to make sure that the workflows in the office will goes smoothly. Meeting or discussion area is important requirement for designer's office as there will be a lot of meetings between designers with clients and supplies. Sufficient storage for material and product samples as well as drawings is important and requires a creative solution in limited spaces.

\section{LIMITATIONS AND SUGGESTIONS FOR FUTURE RESEARCH}

Limited numbers of offices willingly cooperate in this study and accessibility of the selected sites had becomes the 
challenge in order to gather more survey and observation of interior design offices in Kuala Lumpur. Although the study has been carried out for the interior design offices typology, the results can be generalized across other work contexts given the nature of the instrument for data collection. In order to understand the pattern of office design in Kuala Lumpur as well as the problems occurs in the existing design, the researcher intend to focus on specific building types and office layout categories for a comprehensive studies.

\section{REFERENCES}

[1] S. Arora, Office Organization and Management, New Delhi India: House Hold Limited, 1980.

[2] A. Kaplan and S. Aronoff, "Productivity paradox: Worksettings for knowledge work," Facilities, vol. 14, no. 3-4, pp. 6-14, 1996.

[3] I. Altman and E. E. Lett, "The ecology of interpersonal relationships: A classification system and conceptual model," in Social and Psychological Factors in Stress, J. E. McGrathe, Ed. New York: Holt Rinehart, 1969.

[4] G. R. Oldham and N. L. Rotchford, "Relationships between office characteristics and employee reactions: A study of the physical environment," Administrative Science Quarterly, vol. 28, pp. 542-556, 1983.

[5] R. Woods and D. Canter, "The effect of the meaning of buildings on behaviour," Applied Ergonomics, vol. 1, pp. 144-150, 1970.

[6] G. R. Oldham and Y. Fried, "Employee reactions to workspace characteristics," Journal of Applied Psychology, vol. 72, pp. 75-80, 1987.

[7] E. Sundstrom, R. K. Herbert, and D. W. Brown, "Privacy and communication in an open-plan office: A case study," Environment and Behaviour, vol. 14, pp. 379-392, 1982.

[8] L. Block and G. Stokes, "Performance and satisfaction in private versus non private work settings," Environment and Behaviour, vol. 21, pp. 277-297, 1989.

[9] A. Maherand and V. H. Courtney, "Individual differences in employee reactions to open-plan offices," Journal of Environmental Psychology, vol. 25 , no. 2, pp. 219-229, 2005

[10] T. L. S. Jackson and K. W. Klein, "Open-plan offices: Task performance and mental workload," Journal of Environmental Psychology, vol. 29, no. 2, pp. 279-289, 2009.

[11] G. W. Evans and D. Johnson, "Stress and open-office noise," Journal of Applied Psychology, vol. 85, no. 5, p. 779, 2000.
[12] E. Sundstrom, J. P. Town, R. W. Rice, D. P. Osborn, and M. Brill, "Office noise, satisfaction, and performance," Environment and Behavior, vol. 26, no. 2, pp. 195-222, 1994.

[13] H. Edward, The Hidden Dimension: Doubleday, Garden City, 1966.

[14] Y. K. Chan, "Density, crowding, and factors intervening in their relationship: Evidence from a hyper-dense metropolis," Social Indicators Research, vol. 48, no. 1, pp. 103-124, 1999.

[15] F. D. Becker, B. Gield, K. Gaylin, and S. Sayer, "Office design in a community college effect on work and communication patterns," Environment and Behavior, vol. 15, no. 6, pp. 699-726, 1983.

[16] J. Vischer, Environmental Quality in Offices: Van Nostrand Reinhold, New York, 1989.

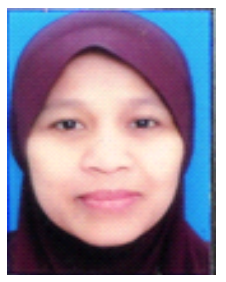

Arita Hanim Awang was born in Sungai Petani, a town in Kedah, Malaysia. She graduated her bachelor degree (Hons) in interior architecture from University Technology Mara (UiTM), Malaysia in 2008 and she obtained her master degree in building science from National University Singapore (NUS) in 2010. She is now a Ph.D candidate in International Islamic University Malaysia (IIUM) in Department of Architecture.

Her Ph.D topic is on office design. She is an academic trainee in the Department of Applied Arts and Design, IIUM and has served as a tutor for interior design studio for a year before doing her full-time study of Ph.D in built environment at IIUM.

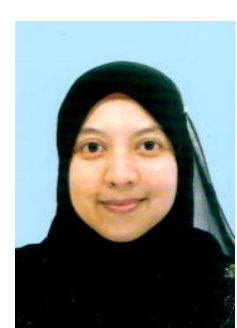

Zuraini Denan is an assistant professor at the Department of Architecture, Kulliyyah of Architecture and Environmental Design, International Islamic University of Malaysia, Kuala Lumpur. She received her bachelor of architecture degree from Texas Tech University, Texas, USA and master degree (MArch) from Universitoi Teknologi Malaysia, Skudai, Johor, Malaysia. Her PhD work is from the Cardiff University where she studied visual comfort (window and lighting under daylight of office buildings in hot humid country).

She involves in the review of the Malaysian standard 2012 under the Department of Malaysian Standard (SIRIM). She is also a member of passive design group of the Japan society for the promotion of Science-Vice Chancellors' Council of National Universities in Malaysia (JSPS-VCC,). She involves in advising on the daylighting issues at Kuala Lumpur airport 2 under EAG consulting SDN bhd. Among her research interest are topics such as environment (window, daylighting and visual comfort), office environment, architectural heritage and culture and human behavior. 